\title{
POLITYKA W MUZYCE, MUZYKA W POLITYCE. PRZYPADEK ZESPOŁU HUCUŁ KALIPSO
}

\author{
Igor Ksenicz \\ Uniwersytet im. Adama Mickiewicza w Poznaniu \\ Poznań, Polska \\ ORCID: 0000-0002-5286-0040

\section{POLITICS IN MUSIC, MUSIC IN POLITICS. CASE OF GUTSUL CALIPSO BAND}

\begin{abstract}
The aim of the article is to answer the question of political involvement of Ukrainian pop music, on the example of Gutsul Calipso (GC) band. Group from Chernivtsi performs "Hutsul-hop", meaning mix of Afroamerican music with Hutsuls folklore. GC songs were subject to author's content analysis, in terms of political content. It was established that GC lyrics raise social issues mainly, politics being an important part. Humorous commentary included in songs may be considered as critics of pathologies existing in Ukraine: paternalism, corruption, favoritism and populism. GC belongs to the group of socially aware representatives of Ukrainian popular culture, promoting modern patriotism.
\end{abstract}

Keywords: popular culture, pop music, politics, Ukraine.

\section{WSTEP}

Związki między polityką a muzyką, w tym muzyką popularną, mają bogatą literaturę ${ }^{1}$. O ile polityczny wymiar polskiej muzyki rozrywkowej jest zagadnieniem szeroko opisywanym przez naukowców i publicystów, o tyle przypadek Ukrainy uchodzi uwadze polskich badaczy. Niesłusznie, ponieważ nasz wschodni sąsiad podlega interesującemu procesowi, w którym jego

Zob.: T. W. Adorno, O muzyce popularnej, thum. J. Kasperski, „Res Facta Nova” 2015, nr 16(25); M. Jeziński, Muzyka popularna jako wehikut ideologiczny, Toruń 2011; I. Massaka, Polityczna funkcja muzyki. Antyteza estetyki autonomii dzieła muzycznego, „Środkowoeuropejskie Studia Polityczne" 2003, nr 1; Eadem, Epifenomenalny i istotowy wymiar muzyki w polityce, „Środkowoeuropejskie Studia Polityczne” 2005, nr 1; A. Zwoliński, Dźwięk w relacjach społecznych, Kraków 2004. 
rodzima kultura popularna toczy walkę o „rząd dusz” nie tylko z zachodnią popkulturą, ale przede wszystkim z przekazem rosyjskim - russkim mirom.

W tym kontekście przedmiotem rozważań będzie twórczość ukraińskiego zespołu Hucuł Kalipso (dalej: HK), którego piosenki zostaną poddane analizie zawartości pod kątem treści politycznych. Autor postara się udzielić odpowiedzi na pytanie o miejsce pochodzącej z Czerniowców formacji wśród zaangażowanych politycznie ukraińskich twórców kultury popularnej.

\section{POLITYCZNY ASPEKT MUZYKI I MUZYCZNY ASPEKT POLITYKI. PRZYPADEK UKRAINY}

Polityka styka się z muzyką od momentu pojawienia się instytucji państwa w starożytności. Skrajnymi przypadkami wpływu władz na sztukę były reżimy totalitarne, w których „państwo przejęło całkowitą kontrolę nad wszelkimi przejawami wolnej twórczości, decydując - w oparciu o ideologiczne priorytety - o rodzaju muzyki dopuszczanej do rozpowszechniania" ${ }^{2}$. W państwach demokratycznych muzykę wykorzystuje się politycznie, jednak w przeciwieństwie do systemów autorytarnych i totalitarnych jest to „wolny wybór artystów, ich decyzja na włączenie się w dyskusję społeczną, sposób na wyrażenie własnych sympatii i antypatii politycznych"3. Muzyka popularna, zwłaszcza rock i rap, bardzo często angażuje się w politykę nie tyle poprzez agitowanie za tą czy inną opcją partyjną lub światopoglądową, ale w formie komentarza rzeczywistości. Kwestią dyskusyjną pozostaje, czy wykorzystanie „mody politycznej” przez twórców ma służyć zdobyciu popularności, czy może jest to „chęć dania wyrazu rzeczywistym poglądom [...] i wyrażenia szczerego komentarza do istotnych kwestii społecznych"4.

W porównaniu z sytuacją w Polsce, przypadek ukraińskiej kultury popularnej jest szczególny. Ukraina podlega procesowi podwójnej neokolonizacji kulturowej. Poza oczywistą dominacją wzorców zachodnich, de facto amerykańskich, Ukraina pozostaje w orbicie wpływów russkogo mira, czyli rosyjskiego projektu hegemonii kulturowej na obszarze postradzieckim. Przekaz rosyjski dominuje we wszystkich obszarach kultury popularnej na Ukrainie: literaturze, filmie, telewizji czy wreszcie muzyce. Wynika to zarówno $\mathrm{z}$ postsowieckiej mentalności społeczeństwa, w tym ukraińskiej oligarchii, jak i zdecydowanie większych możliwości finansowych rosyjskiego państwa i grup przemysłowo-finansowych, przy jednoczesnej słabości ukraińskich instytucji. W takich okolicznościach rozwój ukraińskiej kultury popularnej,

\footnotetext{
A. Zwoliński, op. cit., s. 276.

Ibidem, s. 284.

M. Jeziński, op. cit., s. 63.
} 
w tym muzyki, po 1991 roku był bardzo utrudniony. Pewne gatunki muzyki rozrywkowej albo w ogóle na Ukrainie nie zaistniały, albo nie przebijały się do opinii publicznej. O ile na przykład słuchacz muzyki rockowej mógł już od samego początku wybierać pomiędzy różnymi wykonawcami, o tyle w odniesieniu do rapu w świadomości Ukraińców przez wiele lat istniały tylko dwa zespoły - charkowski „Tanok na Majdani Kongo” (TNMK) i łucki „Tartak”. Oba odwołują się do hiphopowej stylistyki, chociaż ich muzykę właściwiej byłoby określić jako rapcore. Podobnie z muzyką elektroniczną, dla której ścieżkę dopiero w drugiej dekadzie XXI wieku przetarł zespół „Onuka”. Stosunkowo dużą popularnością cieszy się na Ukrainie muzyka czerpiąca z folkloru i łącząca go ze współczesnymi brzmieniami, przede wszystkim rockiem, czego przykładem jest chociażby rozpoznawalny również w Polsce zespół „Hajdamaky”.

Publicystka Kateryna Jatel podzieliła ukraińskich wykonawców muzyki popularnej na trzy grupy ${ }^{6}$. Pierwszą stanowią artyści, którzy nigdy nie angażowali się społecznie, nigdy nie wyrażali publicznie swojego stanowiska i drobiazgowo wybierali kanały przekazu swojej twórczości. Ta grupa jest zdecydowanie najwęższa. Do drugiej należą artyści, którzy nieświadomie stali się częścią polityki, a to dlatego, że ich neutralne teksty nabyły zabarwienia ideologicznego wśród słuchaczy. Trzecia kategoria obejmuje wykonawców, którzy bezpośrednio lub pośrednio mówią o polityce lub wyrażają swoje poglądy poprzez muzykę. Przykładami są grupy „Hajdamaky”, „Ot Vinta” czy „Tartak” i ich piosenki patriotyczne ${ }^{7}$. Zdecydowana większość ukraińskich muzyków nie wyraża jednak wprost swoich poglądów. Z przyczyn merkantylnych wielu z nich koncertuje w Rosji, pomimo agresji tej ostatniej na Ukrainę w 2014 roku, a gdy zapyta się ich, co myślą o konflikcie w Donbasie, odpowiadają najczęściej, że chcą pokoju i że tak naprawdę na wschodniej Ukrainie mamy do czynienia ze sporem między dwoma bratnimi narodami. Podsumowując, należy zgodzić się z K. Jatel, która w następujący sposób oceniła realia ukraińskiej kultury popularnej: „gościnne występy w jakimś kraju

W 2009 roku grupa nagrała wspólny album z zespołem „Voo Voo” (Voo Voo i Haydamaky), a w 2018 roku z pisarzem Andrzejem Stasiukiem (Mickiewicz - Stasiuk - Haydamaky).

6 К. Ятель, «Музика поза політикою»: як довго наші музиканти будуть приховувати свої погляди, [w:] Liroom, [źródło internetowe:] https://liroom.com.ua/blogs/vote_or_die/, dostęp: 29.11 .2020 .

$7 \quad$ Wymienione zespoły odwołują się w swojej twórczości do spuścizny Ukraińskiej Powstańczej Armii, co wywołuje negatywne skojarzenia w Polsce. Głośnym echem odbił się zakaz wjazdu, który polskie Ministerstwo Spraw Wewnętrznych i Administracji nałożyło na grupę „Ot Vinta” w lipcu 2016 roku, za rzekome ,propagowanie UPA”. Zob.: S. Indycka-Rosół, Przemyśl: Ukraiński zespót Ot Vinta miat zagrać koncert podczas Dni Kupały. Teraz ma zakaz wjazdu do Polski, [w:] Super Express Rzeszów, [źródło internetowe:] https://www.se.pl/rzeszow/przemysl-ukrainski-zespol-ot-vitna-mial-zagrac-koncert-podczas-dni-kupaly-teraz-ma-zakaz-wjazdu-do-polski-aa-9jHS-FJ5M-eeCY.html, dostęp: 29.11.2020. 
- to polityka, występy na określonych kanałach telewizyjnych - to polityka, pojawienie się w pewnych programach telewizyjnych - to polityka, wsparcie jakiejś akcji - to polityka, ignorowanie jakiejś akcji - to polityka, występ na czyjejś imprezie korporacyjnej - to polityka"8.

\section{„HUCUŁ KALIPSO”: HISTORIA ZESPOŁU I CHARAKTERYSTYKA TWÓRCZOŚCI}

Zebranie syntetycznych informacji na temat HK napotyka pewną trudność z uwagi na brak oficjalnej, nieoficjalnej zresztą też, strony internetowej zespołu. Podstawowym kanałem komunikacyjnym grupy z publicznością jest profil na Facebooku9, z którego - oprócz bieżących informacji o koncertach, nowych piosenkach itp. - możemy dowiedzieć się jedynie, że HK wykonuje muzykę: jazz, bukowiński folk, hip-hop, reggae, ska i funky z północnej Bukowiny. W uproszczeniu członkowie zespołu swoją twórczość określają jako „hucuł-hop”, a więc połączenie muzyki ludowej (huculskiej) i hip-hopu.

Początki HK ${ }^{10}$ sięgają 1999 roku, kiedy późniejsi wokaliści i twórcy tekstów zespołu, Bohdan Fedczuk i Andrij Rudyk, spotkali się w Czerniowcach z muzykami undergroundowego zespołu reggae „Diamantowo-Zełeni”. Spotkanie nastolatków było na tyle udane, że już pierwsze wspólne próby przyniosły efekt w postaci utworów, które później pojawią się na debiutanckiej płycie HK. Rozmyślając nad nazwą nowej formacji, początkowo pojawiła się propozycja „Bubl-Hum” (pol. Guma Balonowa), szybko zastąpiona przez obecną, którą muzycy usłyszeli - najprawdopodobniej błędnie - w piosence wykonawcy reggae Yellowmana ${ }^{11}$. Odniesienie do karaibskiej muzyki calypso okazało się jednak bardzo trafne w przypadku czerniowieckiego zespołu i przypadło do gustu jego członkom.

Grupa przeszła typową dla młodzieżowych zespołów na Ukrainie drogę od gry w lokalnych klubach, przez konkurs „Czerwona Ruta” (CzR), którego pierwszą edycję w 1989 roku można porównać do polskiego festiwalu w Jarocinie $^{12}$, do rozpoznawalności ogólnokrajowej. HK wystąpił na CzR w 2001

\footnotetext{
8 К. Ятель, op. cit. Wszystkie thumaczenia od autora, jeśli nie wskazano inaczej.

9 ГуиулKaлinco (GutsulCalipso), [w:] Facebook, [źródło internetowe:] https://www.facebook.com/GutsulCalipso, dostęp: 30.11.2020.

10 Na podstawie: Історія Їдного гУиула, [w:] Майдан, [źródło internetowe:] https://maidan. org.ua/arch/culture/1090517607.html,dostęp: 30.11.2020.

11 Вокаліст гурту „Гуиул Каліпсо” Богдан Федчук про прощальний концерт гурту, [w:] YouTube, [źródło internetowe:] https://www.youtube.com/watch?v=ien7HJ-8k_0, dostęp: 30.11.2020.

12 Władze Radzieckiej Ukrainy, podobnie jak PRL, uznały, że nastroje buntującej się młodzieży uda się skanalizować poprzez kontrolowany przez reżim festiwal. Jako lokalizację świadomie wybrano prowincjonalne Czerniowce, do których trudno było dojechać $\mathrm{z}$ oddalonych
} 
roku w Kijowie, gdzie w kategorii „muzyka taneczna” [!] zespół zdobył drugie miejsce (pierwszego nie przyznano). W tym samym roku grupa wzięła udział w konkursie „Perłyny Sezonu” (pol. Perły Sezonu), który - podobnie jak CzR - promował młodych ukraińskich wykonawców. Tutaj HK znowu stanął na drugim stopniu podium, znowu w kategorii „muzyka taneczna” i znowu bez wyłonienia zwycięzcy.

Pierwsze nagrania zespołu realizowano w chałupniczych warunkach na poddaszu, które z czasem zostało przerobione na laboratorium narkotykowe $\mathrm{e}^{13}$. Później grupa pracowała w małym czerniowieckim studiu, które specjalizowało się w muzyce weselnej. Wreszcie HK trafił na lokalnego biznesmena, który zaprosił zespół do założonego przez siebie nowego studia i w tym właśnie miejscu nagrana została pierwsza płyta grupy Рекєт-Гангстєра (2007; pol. Gangsterzy-Reketierzy). Na drugi, i ostatni do tej pory, album (Най Бог бороне; pol. Niech Bóg broni) publiczność musiała czekać aż do 2018 roku. HK pojawił się również na płycie РеформатЦія-2 (2008), na którą złożyły się covery piosenek zespołu TNMK. Grupa nagrała swoją wersję utworu Iвo Бобул o pochodzącej z Czerniowców gwieździe ukraińskiej estrady.

Jak twierdzą sami muzycy, HK jest zespołem koncertowym. Grupa występowała na scenach całej Ukrainy oraz w Europie, między innymi: w Polsce, Czechach, Rumunii, Rosji, na Słowacji i Białorusi. Praca w studio jest dla formacji zajęciem wtórnym. W jednym z wywiadów A. Rudyk powiedział:

nigdy nie chcieliśmy wejść w ukraiński show-business w jego tradycyjnym rozumieniu, chociaż to oczywiste, że tam jest więcej możliwości i forsy. Zawsze imponował nam taki status indie, w którym nikt ci nie dyktuje, kiedy, ile, za ile i o czym grać-śpiewać. Dlatego na pewno pozostaniemy szeroko znani w wąskich kręgach ${ }^{14}$.

Przerwy w aktywności HK wynikały z perturbacji, przez jakie przechodził zespół. Skład grupy kilkakrotnie ulegał zmianie, w szczytowym momencie na scenie pojawiało się osiem osób: dwóch wokalistów, gitarzysta, gitarzysta basowy, perkusista, trębacz, saksofonista i puzonista. Obecnie HK występuje w składzie siedmioosobowym, bez trębacza. Wszyscy członkowie, oprócz

regionów republiki. CzR, wbrew oczekiwaniom władz, okazała się miejscem manifestacji patriotycznej oraz początkiem kariery takich obecnie legendarnych zespołów ukraińskich, jak „Komu Wnyz”, „Braty Hadiukiny” czy „Wopli Widopliasowa”.

13 Produkcją narkotyków parał się gitarzysta zespołu, który za ten proceder został skazany na karę trzech lat pozbawienia wolności. Zob.: Вокаліст..., цит. праця.

14 В. Требуня, Андрій РУДІК: «Нам потрібна культурна децентралізачія», [w:] „Галицький Кореспондент”, [źródło internetowe:] https://gk-press.if.ua/andrij-rudik-nam-potribna-kulturna-detsentralizatsiya/, dostęp: 1.12.2020. 
wokalistów, są profesjonalnymi muzykami, chociaż działalność artystyczna nie zawsze była bądź jest ich podstawowym źródłem utrzymania ${ }^{15}$. Kilku wybrało emigrację zarobkową ${ }^{16}$, jeden $\mathrm{z}$ wokalistów musiał odbyć zasadniczą służbę wojskową, drugi przez pewien okres pracował jako sprzedawca płyt na bazarze.

Miłośników HK zaskoczyła informacja z marca 2020 roku o zakończeniu działalności zespołu i pożegnalnym koncercie. Decyzja była podyktowana wyjazdem dwóch członków grupy do pracy na okręcie wycieczkowym. Ich plany pokrzyżowała jednak pandemia COVID-19. Pożegnalny koncert nie odbył się, a HK wkrótce wznowił działalność - w październiku 2020 roku na platformach streamingowych pojawiły się dwa nowe nagrania.

O tym, skąd zespół czerpie inspiracje, można dowiedzieć się ze wspomnianej informacji opublikowanej na facebookowym profilu HK. Członkowie grupy przyznają, że wpływ na ich muzykę ma również twórczość legendarnego lwowskiego zespołu rockowego „Braty Hadiukiny”. Wartym podkreślenia jest fakt, że HK wykonuje swoje piosenki nie w literackim wariancie języka ukraińskiego, ale żywą gwarą Czerniowców i okolicy, w której słychać dialekt bukowiński i huculski oraz wpływy języków rosyjskiego i rumuńskiego. Lokalna jest również tematyka tekstów. Ich autorzy są bacznymi obserwatorami życia społecznego współczesnej Bukowiny. Piosenki HK opowiadają między innymi o: pracy handlarzy na bazarze, lokalnych i państwowych elitach, służbie wojskowej, prostytucji, taksówkarzach, życiu w domu studenckim, emigracji czy przemycie. Utwory o elitach (Председатіль, pol. Przewodniczacy; Дenymam, pol. Deputowany) mają wyraźne zabarwienie polityczne i one staną się przedmiotem analizy w dalszej części. Polityczne aluzje można odnaleźć również w innych piosenkach, które zostaną omówione na końcu.

Przewodniczacy ${ }^{17}$

Piosenka z pierwszego albumu HK opowiada historię szefa kołchozu:

(Raz, dwa, trzy, cztery) [po rumuńsku: unu, doi, trei, patru]

Refren:

Złapali go koło rady wiejskiej [urzędu gminy]

Bili (Bili)

\footnotetext{
15 Na przykład puzonista utrzymuje się z pracy hydraulika. Jego biografia stała się kanwą nagranej w 2020 roku przez HK piosenki Сантехнік зі Сторожиния (pol. Hydraulik ze Storożyńca).

16 Muzycy wyjeżdżali do pracy między innymi do: Włoch, Hiszpanii, Niemiec i Stanów Zjednoczonych.

17 Tekst ukraiński za: https://www.pisni.org.ua/songs/226192.html, dostęp: 3.12.2020.
} 
Złapali go koło rady wiejskiej

Bili (Bili). Cata brygada

Przewodniczacy, przewodniczacy,

Co ty narobiteś?

Gdybyś tego nie robit - nikt by cię nie bit

Zwrotki:

Już czwarty dzień ludzie we wsi nie maja spokoju

Baby zawodza w panice "Boże, co to będzie?»,

Bo przewodniczacy, $k^{* * *}$ a, narobit tam tyle,

Że gdyby tego nie robit, to nikt by go nie bit

Zarżnat po cichu barana-czempiona

Wędzit go, smażyt $i$ w konsekwencji zjadt

Robotnikom nie wypłacat pensji przez dwa lata

A sam, co roku na wakacje, latat do Rumunii

Z sąsiednimi kotchozami handlowat nawozem,

A pieniadze, które zarabiat, nie deklarowat [nie zgłaszat do opodatkowania] Ani razu nie zapłacit podatku dochodowego,

A za zarobione pieniądze kupit Żyguli [samochód produkcji radzieckiej]

U przewodniczacego pracowała sekretarka Hala

Byta żona brygadzisty kowali.

Szef kotchozu zaprosit ją na filiżankę herbaty [pot. umówit się z nia na seks].

Ona powiedziała «tak» i przyprowadziła męża.

Spotkali go wieczorem, koło jego domu

Trzej kowale z kołchozu i dwóch robotników.

Na poczatku chcieli mu pogratulować,

Ale potem przemyśleli i dołożyli mu

Na szpitalnym tóżku dzielnicowemu Iwanowi

Zeznat wszystko szczegółowo do protokotu.

Że jest bardzo grzeczny $i$ w ogóle niezamożny,

A za złapanie napastników podaruje Żyguli.

Tekst porusza temat kilku ukraińskich patologii społecznych. Pierwszą jest paternalizm. W okresie radzieckim szef kołchozu był najważniejszą osobą we wsi, której status wyznaczało jego członkostwo w partii komunistycznej. Po rozpadzie ZSRR przewodniczący - analogiczni do tego z piosenki - jako 
osoby cieszące się autorytetem na wsi obejmowali ważne posady we władzach lokalnych ${ }^{18}$ lub przejmowali na własność upadające kołchozy w drodze nietransparentnej prywatyzacji, pełniąc niekiedy obie funkcje jednocześnie. Tym samym szefowie kołchozu jako najwięksi pracodawcy na obszarach wiejskich byli „panami życia i śmierci” miejscowej ludności. Nie dziwi zatem „zawodzenie bab”, które boją się o los wsi.

Kolejną patologią opisaną w Przewodniczacym jest neopatrymonialne podejście elit do mienia publicznego, zresztą pochodna paternalizmu, zgodnie z którym politycy uznają majątek państwowy za swoją własność, którą można rozporządzać według własnego uznania. Bohater piosenki ukradł z kołchozu rozpłodowego barana, którego zjadł. Mimo dochodów uzyskiwanych z handlu nawozem, od których nie płacił podatków, zalegał swoim pracownikom z wypłatą wynagrodzeń. Co więcej, z tych pieniędzy finansował sobie wakacje w Rumunii i kupił samochód.

Kara za postępowanie spotkała przewodniczącego dopiero w momencie, gdy swoją pozycję chciał wykorzystać molestując seksualnie podwładną, żonę pracownika kołchozu. Mężczyźni dokonujący samosądu stanęli przed dylematem: czy pogratulować szefowi animuszu, czy dać mu nauczkę? Wygrała mimo wszystko ludowa sprawiedliwość.

Zaistniała sytuacja niczego nie nauczyła przewodniczącego. W szpitalu zeznał bowiem dzielnicowemu, że jest niewinny i biedny. Obiecał ponadto milicjantowi, że podaruje mu (pochodzący z przestępstwa [!]) samochód w nagrodę za złapanie sprawców linczu. W tym miejscu uwidacznia się kolejna ukraińska patologia, jaką jest kumoterstwo i korupcja wśród elit. Trudno przecież spodziewać się, by dzielnicowy odmówił prośbie wysoko postawionego kolegi.

Deputowany ${ }^{19}$

Na poziom elit centralnych przenosi nas piosenka z drugiej płyty HK:

Refren:

Mam wszystko, i chcę mieć jeszcze więcej

Wybierzcie mnie na deputowanego ludowego [parlamentarzystę].

Mam wszystko, i chcę mieć jeszcze więcej

Wybierzcie mnie na deputowanego ludowego.

\footnotetext{
18 Przykład Aleksandra Łukaszenki z sąsiedniej Białorusi pokazuje, że dyrektor kołchozu mógł stanąć nawet na czele państwa.

19 Tekst ukraiński za: https://pesni.guru/text/\%D0\%B3\%D1\%83\%D1\%86\%D1\%83\%D0\% BB-\%D0\%BA $\%$ D0\%B0\%D0\%BB\%D0\%BF\%D1\%81\%D0\%BE-\%D0\%B4\%D0\%B5\%D0\% BF\%D1\%83\%D1\%82\%D0\%B0\%D1\%82, dostęp: 3.12.2020.
} 
Zwrotki:

Od dzieciństwa marzyłem, żeby zostać deputowanym ludowym

Żeby straszyć po pijaku drogówkę z mercedesa

Mieć wolny wstęp do loży bogaczy ${ }^{20}$,

Reszcie śmiertelników przejście zabronione

I mieć staty dostep do systemu Rada ${ }^{21}$,

A kiedy trzeba, blokować trybunę.

Później planuję sprzedać się innej frakcji,

Trzeba przecież jakoś zwrócić koszty przedwyborcze.

Kiedy jestem kandydatem, jestem kumem, bratem, swatem,

Noszę wyborcom produkty spożywcze, całuję wszystkich pod rząd.

Bardzo szczodrze rozdaje obietnice,

Polepszenie życia wraz z moim przyjściem do władzy ${ }^{22}$.

Obrażeni, biedni to mój bazowy elektorat.

A ich tani suchy prowiant zapewni zwycięstwo.

Fryzurka, marynareczka, ładne stówka

Moje docelowe audytorium

Łyknie to

Praca $w$ Radzie Najwyższej jest bardzo trudna,

Należy tam cały dzień głośno się kłócić,

Praca $w$ Radzie Najwyższej jest bardzo trudna,

Należy tam caty dzień bić się o trybune.

W refrenie przedstawiono główną motywację, dla której na Ukrainie rozpoczyna się karierę polityczną: pieniądze. Ukraińskie partie polityczne są w praktyce reprezentantami grup oligarchicznych rzeczywiście rządzących państwem. Stąd też walka o władzę jest de facto przedłużeniem konkurencji gospodarczej. O tym, że działalność partyjną traktuje się jako biznes, świadczy chęć „,sprzedania się” tytułowego deputowanego innej frakcji.

Status parlamentarzysty na Ukrainie oznacza określone przywileje („loża bogaczy”), które wzmacniają poczucie wyższości polityków nad innymi grupami społecznymi. Jednym z nich jest immunitet, który przydaje się w celu ochrony prywatnych interesów oligarchów (,straszyć po pijaku drogówkę z mercedesa").

\footnotetext{
20 W oryginale sztukaturiw. W rosyjskim języku potocznym sztukarik oznacza tysiąc w odniesieniu do pieniędzy (pol. kawałek, paczka, patol).

21 Elektroniczny system obsługi posiedzeń ukraińskiego parlamentu - Rady Najwyższej Ukrainy.

22 Nawiązanie do hasła wyborczego W. Janukowycza (,polepszenie życia już dzisiaj”).
} 
Druga zwrotka jest opowieścią o kolejnej patologii ukraińskiego życia społecznego - populizmie. Zawiera ona również krótką jego definicję: „,bardzo szczodrze rozdaję obietnice, polepszenie życia wraz z moim przyjściem do władzy". Populizm na Ukrainie przyjmuje różne formy, znane również w Polsce. Odpowiednikiem kiełbasy wyborczej na Ukrainie jest hreczka, czyli kasza gryczana opisana w piosence jako „suchy prowiant”. Podmiot liryczny trafnie określa swoją grupę docelową - jest nim elektorat protestu („obrażeni, biedni”). Współcześnie realną walkę polityczną zastępuje marketing, o czym dobrze wie bohater piosenki: „fryzurka, marynareczka, ładne słówka”; ,jestem kumem, bratem, swatem”; „całuję wszystkich pod rząd”.

Najsmutniejszy w całej opowieści jest cel walki politycznej, który słuchacze poznają w ostatniej zwrotce. Okazuje się bowiem, że praca deputowanego sprowadza się do całodziennych kłótni i bójek o trybunę. Równie smutne jest to, że Ukraińcy znają z autopsji zjawiska opisywane w piosence. Kupowanie poparcia politycznego odbywa się wprost poprzez wspomnianą kaszę gryczaną, którą kandydaci ofiarowują wraz z innymi produktami spożywczymi najbiedniejszym, przede wszystkim emerytom. Ta grupa wyborców jest jednocześnie najbardziej zdyscyplinowana, co zapewniło zwycięstwo niejednemu ukraińskiemu burmistrzowi czy parlamentarzyście. Poparcie w Radzie Najwyższej Ukrainy kupuje się twardą walutą. Najbardziej znany, zbiorowy przypadek przekupstwa w parlamencie miał miejsce w 2010 roku, po zwycięstwie W. Janukowycza w wyborach prezydenckich. Do pełni władzy brakowało mu wówczas większości parlamentarnej, którą uzyskał kupując poparcie deputowanych przeciwnego obozu politycznego, nazwanych później tuszkami (pol. tusze).

\section{MOTYWY POLITYCZNE W INNYCH UTWORACH „HUCUŁ KALIPSO”}

Politycznych konotacji można doszukać się w innych piosenkach grupy. Utwór Перефipiя (pol. Peryferie) opowiada o nielegalnym, ukrytym w Karpatach kasynie. Jego właścicielem jest „,przewodniczący gospodarstwa leśnego, tutejsza mafia, za Związku Radzieckiego były kagebista". Zespół komentuje w ten sposób związki pomiędzy radzieckimi służbami specjalnymi, światem przestępczym i współczesnym biznesem ukraińskim. Tajemnicą poliszynela jest kryminalna czy też agenturalna przeszłość niejednego ukraińskiego polityka, by wspomnieć tylko byłego prezydenta W. Janukowycza (dwukrotnie skazanego za pospolite przestępstwa), czy wywodzącego się z półświatka oligarchy, jednocześnie najbogatszego Ukraińca Rinata Achmetowa.

Piosenka Золотая Молодьож (pol. Złota mlodzież) znowu traktuje o kumoterstwie. Jej bohaterami są dzieci prokuratora rejonowego, które można zaliczyć do grupy tzw. mażorów. Pojęcie to oznacza na obszarze postradzieckim pociechy wysoko postawionych rodziców, które dzięki wpływom tych 
ostatnich mają ułatwiony start w dorosłe życie: dostają się na najlepsze uczelnie, otrzymują prestiżowe posady czy też uchodzą im na sucho popełniane przestępstwa, chociażby prowadzenie samochodu pod wpływem alkoholu. Z piosenki dowiadujemy się, że ojciec tytułowej złotej młodzieży przyjaźni się z dyrektorem szkoły (jeżdżą razem na wakacje), do której chodził syn prokuratora. Dzięki tej przyjaźni syna „lubiła” cała kadra nauczycielska, a na balu maturalnym dyrektor uroczyście wręczył mu medal za wyniki w nauce. $\mathrm{W}$ pewnym momencie ojciec zablokował synowi dostęp do pieniędzy i wymógł na nim podjęcie studiów w Mohylance ${ }^{23}$, „bo tato załatwił wszystkie sprawy w rektoracie". Przyszłość chłopaka rysuje się w jasnych barwach: z poddasza mieszkania w elitarnej dzielnicy ogląda w nocy miejskie sztuczne ognie, „w radzie miejskiej siedzi wujek Sławek, u gubernatora [wojewody] siostra, kwestie podatkowe załatwia chrześnica ${ }^{24 "}$.

Utwór Контрабас (pol. Kontrabas, slang. kontrabanda) opowiada historię przemytnika z przygranicznego miasteczka, który zaczynał od drobnej kontrabandy papierosów, a skończył na wywozie całych wagonów drewna ${ }^{25}$. Ważnym motywem w piosence jest ponownie korupcja. HK śpiewa w refrenie, że „,elnicy od dawna nie są dla nas problemem”, a „służby specjalne nie mogą nas zatrzymać". Dlaczego? Ponieważ miejscowi przemytnicy opłacają funkcjonariuszy, dzięki czemu bohater utworu za próbę przetransportowania nielegalnego towaru motolotnią ${ }^{26}$ mógł się wykręcić niewielkim mandatem i łapówką.

\section{ZAKOŃCZENIE}

HK należy do tych twórców ukraińskiej muzyki popularnej, którzy nie stronią od polityki w swoich utworach, będąc bardziej bacznym obserwatorem, niż propagatorem jakiejś konkretnej ideologii. W żartobliwej formie, w którą ubrany jest polityczny komentarz zespołu, wyraża się krytyka zastanych na Ukrainie zjawisk społecznych. Kontynuując myśl K. Jatel można pokusić się o stwierdzenie, że każde działanie popularnego ukraińskiego wykonawcy jest polityczne. W tym sensie HK należy utożsamić z nurtem świadomych społecznie artystów, dla których ważny jest przekaz w języku ukraińskim (w przypadku czerniowieckiego zespołu w jednej z gwar tego języka) i rozwój rodzimej kultury popularnej, w wymiarze zarówno państwo-

\footnotetext{
23 Akademia Kijowsko-Mohylańska, prestiżowa uczelnia w Kijowie.

24 W oryginale fina - słowo z dialektu bukowińskiego pochodzenia rumuńskiego.

25 Nielegalny wyrąb lasu jest ogromnym problemem ekologicznym w ukraińskich Karpatach. Konsekwencją tego procederu są osuwiska ziemne i powodzie regularnie nawiedzające południowo-zachodnią część państwa.

26 Członkowie HK mówili w wywiadach, że to prawdziwa historia.
} 
wym jak i lokalnym. Swego rodzaju nowoczesny patriotyzm, który z jednej strony oznacza troskę o rozwój własnej kultury, a z drugiej piętnuje patologie, na pewno zostanie lepiej przyjęty przez podzieloną kulturowo ukraińską publiczność niż narodowo-patriotyczny, czasami wręcz nacjonalistyczny, przekaz prezentowany chociażby przez Ołeha Skrypkę $e^{27}$.

\section{BIBLIOGRAFIA}

\section{Monografie:}

Jeziński Marek. 2011. Muzyka popularna jako wehikut ideologiczny. Toruń: Wydawnictwo Naukowe Uniwersytetu Mikołaja Kopernika.

Zwoliński Andrzej. 2004. Dźwięk w relacjach społecznych. Kraków: Wydawnictwo WAM.

\section{Artykuły w czasopismach:}

Adorno Theodor W. 2015. O muzyce popularnej. Tłum. J. Kasperski. „Res Facta Nova” nr 16 (25): 75-98.

Massaka Iwona. 2003. Polityczna funkcja muzyki. Antyteza estetyki autonomii dzieła muzycznego. „Środkowoeuropejskie Studia Polityczne” nr 1: 75-94.

Massaka Iwona. 2005. Epifenomenalny $i$ istotowy wymiar muzyki w polityce. „Środkowoeuropejskie Studia Polityczne" nr 1: 155-168.

\section{Publikacje internetowe:}

Âtel' Katerina. "Muzika poza politikoû»: âk dovgo naši muzikanti budut' prihovuvati svoï poglâdi. W: https://liroom.com.ua/blogs/vote or die/ [Dostęp 29.11.2020] [Ятель Катерина. «Музика поза політикою»: як довго наші музиканти будуть приховувати свої погляди].

Indycka-Rosół Sylwia. Przemyśl: Ukraiński zespót Ot Vinta miał zagrać koncert podczas Dni Kupały. Teraz ma zakaz wjazdu do Polski. W: https://www.se.pl/rzeszow/przemysl-ukrainski-zespol-ot-vitna-mial-zagrac-koncert-podczas-dni-kupaly-teraz-ma-zakaz-wjazdu-do-polski-aa-9jHS-FJ5M-eeCY.html [Dostęp 29.11.2020].

Gucul Kalipso (Gutsul Calipso). W: https://www.facebook.com/GutsulCalipso [Dostęp 30.11.2020] [Гуиул Каліпсо (GutsulCalipso)].

İstoriâ Ïdnogo gUcula. W: https://maidan.org.ua/arch/culture/1090517607.html [Dostęp 30.11.2020] [Історія Їдного гУиула].

Trebunâ Vlad. Andrìj RUDİK: «Nam potribna kul'turna decentralizacìa». W: https://gk-press.if.ua/andrij-rudik-nam-potribna-kulturna-detsentralizatsiya/ [Dostęp 1.12.2020] [Требуня Влад. Андрій РУДІК: «Нам потрібна культурна децентралізація»].

Vasilenko Svìtlana. OlegSkripka: Dlâ lûdej, âkì nemožut' vivčiti movu, treba stvoriti getto. W: https://ife.pravda.com.ua/culture/2017/04/20/223718/ [Dostęp 29.11.2020]

27 Lider zespołu „Wopli Widopliasowa” w jednym z wywiadów postulował stworzenie specjalnych gett dla obywateli Ukrainy, którzy nie potrafią nauczyć się języka państwowego. Zob.: С. Василенко, Олег Скрипка: Для людей, які не можуть вивчити мову, треба створити гетто, [w:] „Українська Правда”, [źródło internetowe:] https://life.pravda.com.ua/culture/20 17/04/20/223718/,dostęp: 29.11.2020. Gwoli uczciwości HK dwukrotnie wystąpił na organizowanym przez O. Skrypkę festiwalu „Kraina Mrij” (pol. Kraj Marzeń). 
[Василенко Світлана. Олег Скрипка: Для людей, які не можуть вивчити мову, треба створити гетто].

Vokalist gurtu «Gucul Kalìpso» Bogdan Fedčuk pro proŝal'nij koncert gurtu. W: https:// www.youtube.com/watch?v=ien7HJ-8k_0 [Dostęp 30.11.2020] [Вокаліст гурту «Гуиул Каліпсо» Богдан Федчук про прощальний конщерт гурту].

\title{
POLITYKA W MUZYCE, MUZYKA W POLITYCE. PRZYPADEK ZESPOŁU HUCUŁ KALIPSO
}

Streszczenie: Artykuł stanowi próbę odpowiedzi na pytanie o zaangażowanie polityczne ukraińskiej muzyki popularnej na przykładzie zespołu Hucuł Kalipso (HK). Grupa z Czerniowców wykonuje „hucuł-hop”, czyli połączenie muzyki afroamerykańskiej z folklorem huculskim. Autor poddał piosenki HK analizie zawartości pod kątem treści politycznych. Ustalono, że zespół porusza w swoich tekstach przede wszystkim tematykę społeczną, której istotną część stanowi polityka. Zawarty w utworach żartobliwy komentarz można uznać za krytykę zastanych na Ukrainie patologii: paternalizmu, korupcji, kumoterstwa i populizmu. HK należy do grupy świadomych społecznie przedstawicieli ukraińskiej kultury popularnej, promujących nowoczesny patriotyzm.

Słowa kluczowe: kultura popularna, muzyka popularna, polityka, Ukraina.

\section{ПОЛТТИКА В МУЗИЦІ, МУЗИКА В ПОЛІТИЦІ. ПРИКЛАД ГУРТУ ГУЦУЛ КАЛІПСО}

\begin{abstract}
Анотація: Стаття $є$ спробою відповіді на запитання про політичну заангажованість української популярної музики на прикладі гурту Гуцул Каліпсо (ГК). Група з Чернівців виконує «гуцул-хоп», тобто суміш афроамериканської музики і гуцульського фолклору. У своїх текстах ГК порушує в першу чергу суспільну тематику, важливою частиною якої $є$ політика. Жартівливий коментар присутній у творах можна сприйняти як критику патологій, з якими стикається Україна: патерналізму, корупції, кумівства та популізму. ГК можна віднести до групи суспільно свідомих популярних українських артистів, які просувають сучасний патріотизм.
\end{abstract}

Ключові слова: популярна культура, популярна музика, політика, Україна. 
